\title{
Impact of foliar application of nanomicronutrient fertilizers on some quantitative and qualitative traits of" Thompson seedless" grapevine
}

\author{
Asmaa A. Mohamed \\ Viticulture Dept., Hort. Res. Inst., Agric. Res. Center, Giza, Egypt.
}

Received: 25 April 2020/ Accepted 05 July 2020 / Publication date: 20 July 2020

\begin{abstract}
The present study was carried out during 2017/2018 on forty-five uniform Thompson seedless grapevines grown in a private vineyard at El-badary area, Assiut Governorate. This investigation was aimed to improve the yield and quality of Thompson seedless grape cultivar by using bulk and nano Zinc, iron and manganese. Five treatments were used T1: control (spraying with distilled water), T2: 1500ppm (bulk $\mathrm{Zn}+\mathrm{Fe}+\mathrm{Mn}$ ), T3: 2000ppm (bulk Zn + Fe + Mn), T4: 1500ppm (nano Zn + Fe + Mn),T5: 2000ppm (nano $\mathrm{Zn}+\mathrm{Fe}+\mathrm{Mn}$ ). The obtained results revealed that Using Zinc, iron and manganese bulk or nano significantly increased yield, and improved the cluster and berry traits, and also improved leaf area, leaf total chlorophyll as well as leaf nutrient composition compared to control. While the all treatments resulted in significant increase of TSS/Acid ratio and also significant decreased total acidity (TA \%) compared to control during the two studied seasons. It was evident from the results that nano Zinc, iron and manganese at $1500 \mathrm{ppm}$ the best treatment for improving the yield, cluster and berry traits, leaf area as well as leaf total chlorophyll and nutrient composition compared to the other treatments.
\end{abstract}

Keywords: Grapevines, Thompson seedless, nanomicronutrient, bulk, fertilizers

\section{Introduction}

Grape (Vitis vinifera, L.) is considered as one of the most popular and favorite fruit crops in the world. Because it is the fourth crop all over the world after citrus, apple and bananas. Turkey is the world's largest grape producer followed by The United States of America and then China. In Egypt, grape is considered as one of the main fruits which ranks the second after citrus. The province of Minya occupies the first place in the production of grapes in Egypt followed by Dakahlia and then EL-Gharbia. The total area of grape in Egypt reached about 184078 feddans producing about 1718764 tons according to the Ministry of Agriculture Statistics, Egypt, (2018).

Addition of fertilizers to supplement the natural soil fertility is essential for modern crop production and precise management of nutrient elements for a sustainable agriculture production (Barker and Pilbeam, 2006). In particular, microelements (such as zinc, Iron Manganese, and others) have important roles in fruit set and retention, as well as in fruit yield and quality (Singh and Ram, 1983).

Zinc is one of the essential micronutrients of plants, and $\mathrm{Zn}$ deficiency is common in many crops (Marschner, 2012). Zinc is required for the activity of different enzymes, including dehydrogenases, aldolases, isomerases, transphosphorylases, RNA and DNA polymerases, cell division, maintenance of membrane structure and photosynthesis and also acts as a regulatory cofactor in protein synthesis (Marschner, 2012). Iron is an essential element for plant metabolism; it acts as a cofactor for various enzymes which directly or indirectly involved in DNA synthesis and respiration. Further, It also work as a cofactor for various enzymes involved in redox reactions such as photosynthesis, respiration, and hormone synthesis (Barberon et al., 2011).

According to Álvarez-Fernández et al. (2013) iron deficiency reduced the efficacy of photosynthetic and carbon fixation in plants which ultimately leads to reduced vegetative growth and crop yield. Iron deficiency caused chlorosis in fruit trees (Nijjar, 1990).

Manganese is essential microelement in the production of chlorophyll, Nitrogen metabolism and also aqueous reactions of photosynthesis are affected by manganese. It plays essential roles in reproductive activities, pollination, cell division in meristematic tissues, repair of vascular tissues and metabolism and transfer of carbohydrates (Movahedidehnoy et al., 2009).

Corresponding Author: Asmaa A. Mohamed, Viticulture Dept., Hort. Res. Inst., Agric. Res. Center, Giza, Egypt. E-mail: Asmaaahmed8853@yahoo.com 
Nanotechnology is a newly discovered field allows for advanced research with satisfying results in a variety of fields including agriculture (Jones, 2006). Nanostructured materials typically consist of particles less than $100 \mathrm{~nm}$ in diameter. Due to their size, these materials have properties that are different from micrometric or larger-sized materials. These include differences in physical strength, chemical reactivity, and electrical conductivity. The development of nanotechnology could play an important role in crop management (Nair et al., 2010). In recent years, researchers have studied the effects of nanostructured materials on plant germination and growth; For example, the penetration of nanostructured materials into seeds is thought to be responsible for the significantly higher germination rate and higher biomass production seen in certain plants (Khodakovskaya et al., 2009). Kamiab and Zamanibahramabadi (2016) showed that foliar spraying of nano-chelate super plus (Zinc, Iron and Manganese) on almond increased the different traits, such as yield, length, width and fresh and dry weight of nut, and the concentration of micro elements $(\mathrm{Zn}, \mathrm{Fe}, \mathrm{Cu}$ and $\mathrm{Mn})$ in leaves increased significantly in all treatments.

\section{Material and Methods}

The present study was carried out during two successive seasons of 2017 and 2018 on forty-five uniform Thompson seedless grapevines grown in a private vineyard at El-badary area, Assiut Governorate. The vines were 11 years old at the starting of this experiment and spaced at $2 \times 2.5$ meters apart. The chosen vines were received the usual agriculture practices that are used in the vineyard including irrigation and pest control. Pruning was done on the first week of January during both seasons using cane pruning method with the assistance of double T supporting system, leaving 72 eyes/ vine (six fruiting canes with twelve eyes and six renewal spurs with two eyes).

This investigation was aimed to improve the yield and quality of Thompson seedless grape cultivar by using bulk and nano Zinc, iron and manganese ( zinc $6.11 \%$, iron $6.06 \%$ and manganese $6.05 \%)$.

The treatments were:

T1: Control (spraying with distilled water)

T2: $1500 p p m$ (Bulk Zn $+\mathrm{Fe}+\mathrm{Mn}$ )

T3: 2000ppm (Bulk Zn $+\mathrm{Fe}+\mathrm{Mn}$ )

T4: $1500 \mathrm{ppm}(\mathrm{Nano} \mathrm{Zn}+\mathrm{Fe}+\mathrm{Mn})$

T5: 2000ppm (Nano Zn + Fe + Mn)

The following parameters were measured for both seasons:

\section{Yield and Cluster characteristic}

At harvest date (mid of July), the yield per vine in terms of weight ( $\mathrm{kg} / \mathrm{vine}$ ) was determined.

And two clusters were randomly taken from each vine to determine the cluster weight and size.

Physical traits: Berry weight $(\mathrm{g})$, length $(\mathrm{mm})$ and diameter $(\mathrm{mm})$ were determined.

\section{Chemical traits:}

Total soluble solids by refractometer and total acidity (expressed as gm tartaric acid per $100 \mathrm{ml}$ juice), berry properties were evaluated according to A.O.A.C, (1985).

\section{Total chlorophyll content:} Minolta.

Total chlorophyll content (\%) were determined by using chlorophyll meter, SPAD-502 Konica

\section{Leaf area $\left(\mathrm{cm}^{2}\right)$ :}

Twenty leaves from those opposite to basal clusters were measured according to the following equation; Leaf area $=0.56\left(0.79 \mathrm{x} \mathrm{w}^{2}\right)+20.01$, where, $\mathrm{w}=$ the maximum leaf width Ahmed and Morsy, (1999) 


\section{Leaf nutritional status:}

Concentration of $\mathrm{Zn}, \mathrm{Fe}$ and $\mathrm{Mn}$ in leaves was measured by the Inductively Coupled Plasma system (Jons et al., 1991).

\section{Statistical analysis:}

The experiment was laid out in complete randomized design (CRD) counting with five treatments and three replications with three vine per each. All the obtained data were tabulated and analyzed according to Gomez and Gomez, (1984) using L.S.D. test for distinguishing the significance differences between various treatment means according to Steel and Torrie (1980).

\section{Results}

\section{1- Yield and cluster characteristics:}

The yield weight (kg/vine) of Thompson seedless grapevines subjected to the various treatments is presented in Table 1. The results revealed that (Nano $\mathrm{Zn}+\mathrm{Fe}+\mathrm{Mn}$ at 1500ppm) produced the highest yield followed by (Nano $\mathrm{Zn}+\mathrm{Fe}+\mathrm{Mn}$ at2000ppm) and (bulk $\mathrm{Zn}+\mathrm{Fe}+\mathrm{Mn}$ at1500ppm (10.29, 9.61 and $9.04 \mathrm{~kg} /$ vine respectively) as an average of two seasons. While the control vines gave the lowest yield among all the treatments $(8.37 \mathrm{~kg} /$ vine as an average of two seasons), The results revealed that the treatments produced significant differences comparing with the control in respect of the cluster weight. The best result of cluster weight was recorded after treatment with nano $\mathrm{Zn}+\mathrm{Fe}+\mathrm{Mn}$ at $1500 \mathrm{ppm}$ (393.15 g), whereas the control vines gave the lowest cluster weight (333.66g) as an average of two seasons. And also the plants treated with nano $\mathrm{Zn}+\mathrm{Fe}+\mathrm{Mn}$ at $1500 \mathrm{ppm}$ gave the best results of cluster length and width $(23.96,14.97 \mathrm{~cm}$ respectively) comparing with the control $((19.96$ and $12.47 \mathrm{~cm}$ respectively) as an average of two seasons. These results of the present investigation agree with those of Alloway (2008), Khan et al. (2012) and Song et al. (2015).they found Zn, Fe and Mn increased the vine yield potential by extending cluster height and cluster width.

Table 1: Effect of foliar application of nanomicronutrient fertilizers on yield ( $\mathrm{kg} / \mathrm{vine})$, cluster weight $(\mathrm{g})$, cluster length $(\mathrm{cm})$ and cluster width $(\mathrm{cm})$ of Thompson seedless grapevines during 2017 \& 2018 seasons.

\begin{tabular}{cccccccc}
\hline \multirow{2}{*}{ Treatments } & \multicolumn{3}{c}{ Yield (kg/vine) } & \multicolumn{3}{c}{ Cluster weight (g) } \\
\cline { 2 - 7 } T1 & $\mathbf{2 0 1 7}$ & $\mathbf{2 0 1 8}$ & Mean & $\mathbf{2 0 1 7}$ & $\mathbf{2 0 1 8}$ \\
T2 & 8.24 & 8.51 & 8.37 & 323.00 & 344.33 & 333.66 \\
& T3 & 8.57 & 9.52 & 9.04 & 333.33 & 366.67 & 350.00 \\
& T4 & 8.24 & 9.23 & 8.73 & 344.00 & 370.00 & 357.00 \\
& T5 & 9.62 & 10.97 & 10.29 & 379.63 & 406.40 & 393.15 \\
LSD (0.05) & 9.17 & 10.07 & 9.61 & 366.33 & 382.33 & 374.33 \\
\hline
\end{tabular}

Table 1: Continued

\begin{tabular}{ccccccc}
\hline & Characters & \multicolumn{3}{c}{ Cluster length( cm) } & \multicolumn{3}{c}{ Cluster width( cm) } \\
\cline { 2 - 7 } Treatments & $\mathbf{2 0 1 7}$ & $\mathbf{2 0 1 8}$ & Mean & $\mathbf{2 0 1 7}$ & $\mathbf{2 0 1 8}$ & Mean \\
\hline T1 & 19.53 & 20.40 & 19.96 & 12.33 & 12.60 & 12.47 \\
T2 & 21.26 & 21.06 & 21.16 & 13.03 & 13.73 & 13.38 \\
T3 & 22.56 & 22.33 & 22.45 & 13.70 & 14.47 & 14.08 \\
T4 & 23.40 & 24.53 & 23.96 & 14.23 & 15.70 & 14.97 \\
T5 & 23.40 & 24.00 & 23.70 & 14.23 & 15.43 & 14.83 \\
LSD (0.05) & 0.75 & 1.70 & & 1.00 & 1.10 & \\
\hline
\end{tabular}

T1: Control (Spraying with distilled water); T2: 1500ppm (Bulk Zn + Fe + Mn); T3: 2000ppm (Bulk Zn + Fe + Mn); T4: 1500ppm (Nano Zn + Fe + Mn); T5: 2000ppm (Nano Zn + Fe + Mn)

\section{Physical traits:}

Data of the berry weight $(\mathrm{g})$, berry length $(\mathrm{mm})$ and berry diameter $(\mathrm{mm})$ which were subjected to various treatments are shown in Table 2 . The results of berry weight showed significant differences among all the treatments during the two seasons of study. Vines treated with nano $\mathrm{Zn}+\mathrm{Fe}+\mathrm{Mn}$ at $1500 \mathrm{ppm}$ were the heaviest berries (1.52 and $1.533 \mathrm{~g}$. for the two seasons, respectively) among all the 
treatments. The berry length $(\mathrm{mm})$ took the same trend of berry weight. The superior treatment was nano $\mathrm{Zn}+\mathrm{Fe}+\mathrm{Mn}$ at $1500 \mathrm{ppm}$ followed by nano $\mathrm{Zn}+\mathrm{Fe}+\mathrm{Mn}$ at 2000ppm 15.50, $14.98 \mathrm{~mm}$ respectively comparing to control $(13.42 \mathrm{~mm})$. Data presented in the same Table showed also that berry diameter significantly affected by the four treatments, nano $\mathrm{Zn}+\mathrm{Fe}+\mathrm{Mn}$ at $1500 \mathrm{ppm}$ gave the highest values of berry diameter $(13.76 \mathrm{~mm})$, while the lowest values were associated with the control (11.96 $\mathrm{mm}$ ). Allaway (2008) was found that spraying the grapevines with Zinc, iron and manganese increased berry weight, berry length and berry diameter.

Table 2: Effect of foliar application of nanomicronutrient fertilizers on some physical traits of Thompson seedless grapevines during 2017 \& 2018 seasons

\begin{tabular}{cccccccccc}
\hline Characters & \multicolumn{3}{c}{ Berry weight } & \multicolumn{3}{c}{$\begin{array}{c}\text { Berry length } \\
(\mathbf{m m})\end{array}$} & \multicolumn{3}{c}{$\begin{array}{c}\text { Berry diameter } \\
(\mathbf{m m})\end{array}$} \\
\cline { 2 - 10 } Treatments & $\mathbf{2 0 1 7}$ & $\mathbf{2 0 1 8}$ & Mean & $\mathbf{2 0 1 7}$ & $\mathbf{2 0 1 8}$ & Mean & $\mathbf{2 0 1 7}$ & $\mathbf{2 0 1 8}$ & Mean \\
\hline T1 & 1.3033 & 1.4033 & 1.35 & 13.233 & 13.600 & 13.42 & 11.667 & 12.267 & 11.96 \\
T2 & 1.4067 & 1.4233 & 1.41 & 14.27 & 14.53 & 14.40 & 12.43 & 12.6 & 12.51 \\
T3 & 1.4467 & 1.4333 & 1.44 & 14.70 & 14.80 & 14.75 & 12.64 & 13.40 & 13.02 \\
T4 & 1.5200 & 1.5333 & 1.53 & 15.37 & 15.63 & 15.5 & 13.73 & 13.80 & 13.76 \\
T5 & 1.5133 & 1.5300 & 1.52 & 14.77 & 15.20 & 14.98 & 13.37 & 13.73 & 13.55 \\
LSD (0.05) & 0.069 & 0.068 & & 0.47 & 0.55 & & 0.36 & 0.35 & \\
\hline
\end{tabular}

T1: Control (Spraying with distilled water); T2: 1500ppm (Bulk Zn + Fe + Mn); T3: 2000ppm (Bulk Zn + Fe + Mn); T4: 1500ppm (Nano Zn + Fe + Mn); T5: 2000ppm (Nano Zn + Fe + Mn)

\section{Chemical traits:}

Results in Table (3) showed the differences among the all treatments in respect of total soluble solids (TSS), total acidity(TA) and total soluble solids / total acidity ratio, The highest percentages of TSS were obtained from nano $\mathrm{Zn}+\mathrm{Fe}+\mathrm{M}$ at 1500ppm 20.93 and the lowest percentages of TSS were obtained from Control 19.25. The acidity(TA) of various treatments revealed that the highest percentage of acidity was obtained from Control 0.518 and the least concentrations gave $0.448,0.439$ and $0.426 \%$, respectively as an average of the two seasons of study. Concerning the values of TSS/acidity, the presented results (Table 3) revealed that the highest percentage of TSS/ acidity was obtained from nano $\mathrm{Zn}+\mathrm{Fe}+\mathrm{M}$ at $1500 \mathrm{ppm} 49.24$ While, the lowest TSS/acidity was obtained from Control 37.00.This result was agree with Krizsics and Diofasi (2007) and Song et al. (2015)

Table 3: Effect of foliar application of nanomicronutrient fertilizers on some chemical traits of Thompson seedless grapevines during 2017 \& 2018 seasons

\begin{tabular}{cccccccccc}
\hline Characters & \multicolumn{2}{c}{ Total soluble solids (TSS) } & \multicolumn{3}{c}{$\begin{array}{c}\text { Acidity (TA) } \\
\text { (\%) }\end{array}$} & \multicolumn{3}{c}{ \%) } & \multicolumn{3}{c}{$\begin{array}{c}\text { TSS/TA } \\
\text { (\%) }\end{array}$} \\
\cline { 2 - 10 } Treatment & $\mathbf{2 0 1 7}$ & $\mathbf{2 0 1 8}$ & Mean & $\mathbf{2 0 1 7}$ & $\mathbf{2 0 1 8}$ & Mean & $\mathbf{2 0 1 7}$ & $\mathbf{2 0 1 8}$ & Mean \\
\hline T1 & 19.10 & 19.40 & 19.25 & 0.522 & 0.504 & 0.518 & 36.59 & 37.44 & 37.00 \\
T2 & 18.80 & 19.83 & 19.31 & 0.494 & 0.418 & 0.456 & 38.02 & 47.43 & 42.72 \\
T3 & 19.30 & 19.93 & 19.62 & 0.465 & 0.431 & 0.448 & 41.50 & 46.21 & 43.85 \\
T4 & 20.50 & 21.36 & 20.93 & 0.432 & 0.418 & 0.425 & 47.40 & 51.08 & 49.24 \\
T5 & 20.06 & 20.13 & 20.10 & 0.465 & 0.413 & 0.439 & 47.56 & 48.70 & 48.13 \\
LSD $(\mathbf{0 . 0 5})$ & N.S & 0.988 & & 0.016 & 0.022 & & 1.122 & 4.225 & \\
\hline
\end{tabular}

T1: Control (Spraying with distilled water); T2: 1500ppm (Bulk Zn + Fe + Mn); T3: 2000ppm (Bulk Zn + Fe + Mn); T4: 1500ppm (Nano Zn + Fe + Mn); T5: 2000ppm (Nano Zn + Fe + Mn)

\section{Leaf area and total chlorophyll content}

Data presented in Table (4) showed the effect of nano $\mathrm{Zn}+\mathrm{Fe}+\mathrm{Mn}$ fertilization on leaf area and total chlorophyll of Thompson seedless grapevines during 2017 and 2018 seasons. It is obvious from the data that the results took similar trend during the two studied seasons. In a general view, the applications of $\mathrm{Zn}+\mathrm{Fe}+\mathrm{Mn}$ bulk or nano were significantly increased leaf area and total chlorophyll compared to control. The maximum values of leaf area and total chlorophyll were recorded with nano 
$\mathrm{Zn}+\mathrm{Fe}+\mathrm{Mn}$ at $1500 \mathrm{ppm} 196.50 \mathrm{~cm}^{2}$ and $46.85 \mathrm{~cm}^{2}$ respectively, while control recorded the lowest values of leaf area and total chlorophyll as an average of the two studied seasons.

Table 4: Effect of foliar application of Nano micronutrient fertilizers on some leaf traits of Thompson seedless grapevines during 2017 \& 2018 seasons

\begin{tabular}{ccccccc}
\hline Characters & \multicolumn{3}{c}{ Leaf area $\left(\mathbf{c m}^{\mathbf{2}}\right)$} & \multicolumn{3}{c}{ Total chlorophyll } \\
\cline { 2 - 7 } Treatments & $\mathbf{2 0 1 7}$ & $\mathbf{2 0 1 8}$ & Mean & $\mathbf{2 0 1 7}$ & $\mathbf{2 0 1 8}$ & Mean \\
\hline T1 & 175.23 & 178.67 & 176.95 & 39.233 & 41.400 & 40.32 \\
T2 & 177.07 & 184.33 & 180.7 & 41.433 & 43.733 & 42.58 \\
T3 & 186.00 & 189.33 & 187.66 & 42.333 & 45.367 & 43.84 \\
T4 & 195.00 & 198.00 & 196.50 & 46.667 & 47.033 & 46.85 \\
T5 & 193.67 & 195.33 & 194.50 & 45.033 & 46.933 & 45.98 \\
LSD (0.05) & 6.70 & 4.30 & & 2.04 & 2.55 & \\
\hline
\end{tabular}

T1: Control (Spraying with distilled water); T2: 1500ppm (Bulk Zn + Fe + Mn); T3: 2000ppm (Bulk Zn + Fe + Mn); T4: 1500ppm (Nano Zn + Fe + Mn); T5: 2000ppm (Nano Zn + Fe + Mn)

\section{Leaf nutritional status}

The results in Table 5 revealed that Foliar $\mathrm{Zn}+\mathrm{Fe}+\mathrm{Mn}$ nano and bulk treatments had significant effects on leaf content from zinc, iron and Mn. Increasing zinc concentrations were observed with all treatment . The lowest content of zinc was observed in control treatment. The greatest zinc content was observed in (nano $\mathrm{Zn}+\mathrm{Fe}+\mathrm{Mn}$ at 2000ppm) $(37.7 \mathrm{ppm})$. Scardena et al. (1999) indicated that the greatest zinc concentrations should be between $30-50 \mathrm{ppm}$. The greatest iron content in leaf was observed in(nano $\mathrm{Zn}+\mathrm{Fe}+\mathrm{Mn}$ at 2000ppm) $(180.0 \mathrm{ppm})$, while the lowest content was observed in (bulk $\mathrm{Zn}+\mathrm{Fe}+\mathrm{Mn}$ at $1500 \mathrm{ppm}(163.1 \mathrm{ppm})$. All these concentrations were within the limiting values specified by Singh and Singh (1983); Fregoni (1984) and Mills and Jones (1996) (50- 300 ppm; 60$175 \mathrm{ppm})$. In respect of manganese content, the effects of foliar spray treatments on leaf manganese content were significant, the greatest value was recorded with nano $\mathrm{Zn}+\mathrm{Fe}+\mathrm{Mn}$ at 2000ppm (37.40 $\mathrm{ppm}$ ) and it was followed by nano $\mathrm{Zn}+\mathrm{Fe}+\mathrm{Mn}$ at 1500ppm (37.10 ppm) Fregoni (1984) reported manganese concentrations as between $20-400 \mathrm{ppm}$ and such values indicated that all treatments, including control treatment, had sufficient manganese nutrition. Results of Mn content in the study is similar to results obtained by Gunes et al. (2015).

Table 5: Effect of foliar application of Nano micronutrient fertilizers on leaf $\mathrm{Zn}, \mathrm{Fe}$ and $\mathrm{Mn}$ content of Thompson seedless grapevines during $2017 \& 2018$ seasons.

\begin{tabular}{cccccccccc}
\hline Characters & \multicolumn{3}{c}{$\begin{array}{c}\text { Leaf content } \\
\text { (Zn ppm) }\end{array}$} & \multicolumn{3}{c}{$\begin{array}{c}\text { Leaf content } \\
\text { (Fe ppm) }\end{array}$} & \multicolumn{3}{c}{$\begin{array}{c}\text { Leaf content } \\
\text { (Mn ppm) }\end{array}$} \\
\cline { 2 - 10 } Treatment & $\mathbf{2 0 1 7}$ & $\mathbf{2 0 1 8}$ & Mean & $\mathbf{2 0 1 7}$ & $\mathbf{2 0 1 8}$ & Mean & $\mathbf{2 0 1 7}$ & $\mathbf{2 0 1 8}$ & Mean \\
\hline T1 & 35.38 & 36.1 & 35.74 & 172.2 & 171.1 & 171.6 & 37.12 & 35.3 & 36.2 \\
T2 & 35.91 & 36.5 & 36.21 & 156.1 & 170.0 & 163.1 & 36.3 & 34.6 & 35.4 \\
T3 & 35.42 & 37.3 & 36.36 & 160.2 & 170.4 & 165.3 & 33.7 & 33.2 & 33.5 \\
T4 & 36.30 & 37.7 & 37.00 & 175.2 & 172.4 & 173.8 & 36.7 & 37.5 & 37.1 \\
T5 & 37.2 & 38.2 & 37.7 & 187.1 & 172.9 & 180.0 & 36.9 & 37.9 & 37.4 \\
LSD (0.05) & 1.16 & 0.84 & & 2.69 & .97 & & 1.39 & 1.15 & \\
\hline
\end{tabular}

T1: Control (Spraying with distilled water); T2: 1500ppm (Bulk Zn + Fe + Mn); T3: 2000ppm (Bulk Zn + Fe + Mn); T4: 1500ppm (Nano Zn + Fe + Mn); T5: 2000ppm (Nano Zn + Fe + Mn)

\section{Discussion}

In this research, fertilizer spraying of nano $\mathrm{Zn} \mathrm{Fe} \mathrm{Mn} \mathrm{on} \mathrm{Thompson} \mathrm{seedless} \mathrm{grapevines} \mathrm{played}$ an important role in improving the yield and increasing the generative growth and fruit production. This test showed that this fertilizer is absorbed by leaves sufficiently and the concentration of tested microelements increased in leaves compared to control. Leaf area is an important factor in the absorption of treated material from the nutrient solution that is sprayed. The nutrients absorb from cuticle or stomata on the leaf surface. When the stomata are closed, nutrient solutions are absorbed through water pores and the cuticle. Hence, the stomata are important and they can absorb aqueous 
solutions (Bybordi and Malakuti, 2005). If microelements are used as fertilizer in the soil, they will bond with soil particles and will not be absorbed easily by plant roots. Despite of the sufficient concentration of these elements in the soil, absorption by plant roots decreases and it will cause reduction of root growth and reduction of the product and its quality (Kamiab and Zamanibahramabadi, 2016) . Thus, foliar spraying is an efficient way for nutrition.

Zinc is an essential element for the normal and healthy growth and reproduction of plants. When the supply of plant available zinc is inadequate, crop yields are reduced and the quality of crop products is frequently impaired (Sarwar, 2011). This is attributed to the positive effect of zinc fertilizer on auxin biosynthesis that can stimulate cell division and better absorption of minerals and thus increase the plant growth (Cakma, 2000).The higher growth promoting hormone contents in response to the application of $\mathrm{Zn}$ may be due to the fact that zinc has an effect on building up the natural auxin (IAA) and consequently activating the cell division and enlargement (El-Tohamy, and El -Greadly, 2007).

In plants, zinc plays a key role as a structural constituent or regulatory co-factor of a wide range of different enzymes in many important biochemical pathways and these are mainly concerned with carbohydrate metabolism (both in photosynthesis and in the conversion of sugars to starch), protein metabolism, auxin (growth regulator) metabolism, pollen formation, maintaining the integrity of biological membranes, and the resistance to infection by certain pathogens (Alloway, 2008).

Manganese is needed for the activity of some enzymes involved in photosynthesis and protein synthesis (Fernandes et al., (1999). Iron also influences on the production of chlorophyll and carbohydrates in plant. Thus in iron and manganese deficiency, yield and fruit size are severely reduced (Jonesa et al., 2005).

\section{Conclusion}

From the above results it could be concluded that the application of nano ZFM is a good method to remove nutrient deficiencies and increase quantity and quality of Thompson seedless grapevines in the near future. It was also noted that the application of nano $\mathrm{Zn}+\mathrm{Fe}+\mathrm{Mn}$ at $1500 \mathrm{ppm}$ was very effective in improving yield and quality of grapevines.

\section{Reference}

Ahmed, F.F. and M.H. Morsy, 1999. A new method for measuring leaf area in different fruit crops. Minia J. of Agric. Res. \& Develop., 19: 97-105.

Alloway, B.J., 2008. Zinc in soils and Crop Nutrition. International Zinc Fertilizer Industry Association, Brussels Belgium, PP. 30-50.

Alvarez, F., P. Paniagua, J. Abadia, and A. Abadia, 2013. Effects of Fe deficiency chlorosis on yield and fruit quality in Peach (Prunus persica L. Batsch) Journal of Agricultural and Food Chemistry, 51:5738-5744.

A.O.A.C, 1985. Association of Official Agricultural Chemists, Official Methods of Analysis A.O.A.C. Benjamin Franklin Station, Washington, D.C.M.S.A. pp: 440-512.

Barberon, M., E. Zelazny, S. Robert, G. Conjero, C. Curic, J. Friml and G. Ver , 2011 . Monoubiquitindependent endocytosis of the iron regulated transporter 1(IRT 1) transporter controls iron uptake in plants. Proceedings of the National Academy of Sciences of the United States of America Journal (PNAS) 108:450-458.

Barker, A.V. and D.J. Pilbeam, 2006. Handbook of plant nutrition. CRC press ISBN9780824759049.

Baybordi, A. and Mg. Malekuti, 2005. Effect of foliar spraying of N, B and Zn on almond fruit set. Journal of Research and Development. 68: 32-40.

Cakmak, I., 2000. 'Possible roles of zinc in protecting plant cells from damage by reactive oxygen species'. New Phytol, 146: 185-205.

El-Tohamy, W.A. and N.H.M. El-Greadly, 2007. 'Physiological responses, growth, yield and quality of snap bean in response to foliar application of yeast, vitamin $\mathrm{E}$ and zinc under sandy soil conditions'. Australian Journal of basic Applied Sciences, 1: 249-299.

Fernandes L., S. Steven and G.C. Martin, 1999. Olive production manual. University of California. Davis. pp.156.

Fregoni, M., 1984. Nutrient needs in vine production. Institute Bern., 319-332. 
Gomez, K.A. and A.A. Gomez. 1984. Statistical Procedures for Agricultural Research, 2nd Ed. Willy, New York.

Gunes, A., C. Kose, and M. Turan, 2015. Yield and mi- neral composition of grapevine as affected by boron management. Turk. J. Agric. For., 39: 742-752.

Jones, J. R., J.B. Wolf, and H.A. Mills, 1991. Plant Analysis Handbook: A Practical Sampling Preparation Analysis and Interpretation Guide. Micro Macro Publishing Inc. Athens, Georgia, USA.

Jones, P., 2006. "A nanotech revolution in agriculture and the food industry. Information Systems for Biotechnology.

Jonesa David, L., J. D. Shannon, F. Thippaya and F. John, 2005. Plant capture of free amino acids is maximized under high soil amino acid concentrations. Soil Biology \& Biochemistry. 37: 179181.

Kamiab, F. and E. Zamanibahramabadi, 2016 .The Effect of Foliar Application of Nano-chelate Super Plus ZFM on Fruit Set and some Quantitative and Qualitative Traits of Almond Commercial Cultivars. Journal of Nuts, 7(1):9 - 20

Khan, A. S., W. Ullah, A.U. Malik, R. Ahmad, B.Saleem, and J.A. Rajwana, 2012).Exogenous applications of boron and zinc influence leaf nutrient status, tree growth and fruit quality of Feutrell ,s early ( Citrus reticulate Blanco). Pak .J. Agric. Sci., 49:113-119.

Khodakovskaya, M., E. Dervishi, M. Mahmood, Y. Li, Z. Xu, F. Watanabe, and A.S. Biris, 2009. Carbon nano tubes are able to penetrate plant seed coat and dramatically affect seed germination and plant growth. ACS Nano, 3(10):3221-3227.

Krizsics, A.C. and L. Diofasi, 2007. Investigations into the correlation between boron concentration and yield characteristics with the grape cultivar "Cabernet Sauvignon" on different rootstocks. Mitteilungen Klosterneuburg, 57: 213-223.

Marschner, H., 2012. Mineral nutrition of higher plants. Academic Press Limited Harcourt Brace and company, Publishers, London, PP.347 - 364.

Mills, H.A., and J.B. Jones, 1996. Plant analysis handbook II. A practical sampling, preparation, analysis, and interpretation guide. Micro-Macro Publishers, Athens.

Ministry of Agriculture, 2018. Economic Agriculture, Department of Agriculture Economic and statistics Egypt.

Movahedidehnoy, M., A. M. Modaressanevi, A. Soruszadeh, and M. Jalali, 2009. Changes of proline, soluble sugar and chlorophyll in Safflower under drout stress and foliar spraying of $\mathrm{Zn}$ and $\mathrm{Mn}$. Desort Journal, 9: 93-107.

Nair, R.S., H. Varghese, B.G. Nair, T. Maekawa, Y. Yoshida and D.S. Kumar, 2010. Plant Sci., 179:154-163

Nijjar, G.S., 1990. Nutrition of fruit trees. Kalyani Publication New Delhi., India, 259-270.

Sarwar, M., 2011. 'Effects of zinc fertilizer application on the incidence of rice stem borers (Scirpophaga species) (Lepidoptera pyralidae) in rice (Oryza sativa L.) crop'. Journal of Cereals and Oil seeds, 2(5):61-65.

Scardena, D., J. Hoffeltt, S. M. Funt, and J. Buratti, 1999. Tissue analysis for small fruit sampling, critical values and fertilizer recommendations. Midwest Small Fruit Pest Management Handbook, Bulletin, 861, 6 .

Singh, R. S. and S. Ram, 1983. Studies on the use of Palm growth substances for fruit retention in mango cv. Dashehair. Indian Hort., 40: 180-194.

Singh, V. and S.P. Singh, 1983. Effect of applied boron on the chemical composition of lentil plants. J. Indian Soc. Soil Sci., 31: 169-170.

Song, C.Z., M.YT. Liu, J.F. Meng, M. Chi, Z.M. Xi, and Z.W. Zhang, 2015. Promoting effect of foliage sprayed zinc sulfate on accumulation of sugar and phenolics in berries of Vitis vinifera cv. Merlot growing on zinc deficient soil. Molecules, 20: 2436-2554.

Steel, R. G. D. and J. H. Torrie, 1980. Principles and procedures of statistics: Biometrical approach McGrow Hill Book company $\left(2^{\text {nd }}\right.$ Ed) N.Y, 631. 